\title{
Lumen
}

Selected Proceedings from the Canadian Society for Eighteenth-Century Studies

\section{Epistolary Machinations: The Role of Letters in the Construction of Identity in J. M. R. Lenz's Der Waldbruder (The Hermit)}

\section{Edward T. Potter}

Volume 29, 2010

URI : https://id.erudit.org/iderudit/1012032ar

DOI : https://doi.org/10.7202/1012032ar

Aller au sommaire du numéro

Éditeur(s)

Canadian Society for Eighteenth-Century Studies / Société canadienne d'étude du dix-huitième siècle

ISSN

1209-3696 (imprimé)

1927-8284 (numérique)

Découvrir la revue

Citer cet article

Potter, E. T. (2010). Epistolary Machinations: The Role of Letters in the

Construction of Identity in J. M. R. Lenz's Der Waldbruder (The Hermit). Lumen, 29, 143-159. https://doi.org/10.7202/1012032ar

Copyright (C Canadian Society for Eighteenth-Century Studies / Sociéte canadienne d'étude du dix-huitième siècle, 2010
Ce document est protégé par la loi sur le droit d'auteur. L'utilisation des services d'Érudit (y compris la reproduction) est assujettie à sa politique d'utilisation que vous pouvez consulter en ligne.

https://apropos.erudit.org/fr/usagers/politique-dutilisation/ 


\section{Epistolary Machinations: The Role of Letters in the Construction of Identity in J. M. R. Lenz's Der Waldbruder (The Hermit)}

In 1797, Friedrich Schiller requested that Johann Wolfgang von Goethe hand over a manuscript that Goethe's former friend Jakob Michael Reinhold Lenz (1751-92) had once given to him, for Schiller wanted to publish it in his literary journal The Horae (Die Horen, 1795-97). ${ }^{1}$ The text in question was Lenz's fragmentary epistolary novel Der Waldbruder: Ein Pendant zu Werthers Leiden (The Hermit: A Counterpart to Werther's Sufferings), a text which was written in 1776 and which engages with a variety of issues and texts from the 1770 s. $^{2}$ This text marks itself programmatically in its subtitle as a companion piece to Goethe's successful and influential epistolary novel, The Sufferings of Young Werther (Die Leiden des jungen Werther, $1774,2^{\text {nd }}$ ed. 1787). Lenz has at times been seen as a marginalized literary figure or an epigonic reflection of Goethe, an impression that was already being propagated by Goethe himself in the fourteenth book of his work of autobiographical "faction," Poetry and Truth (Dichtung und Wahrheit, 1811-14). ${ }^{3}$ My essay, however, focuses on

1 See Sigrid Damm's comments in Jakob Michael Reinhold Lenz, Werke und Briefe in drei Bänden, ed. Sigrid Damm, vol. 2, (Munich: Hanser, 1987), 871-72.

2 Jakob Michael Reinhold Lenz, Der Waldbruder: Ein Pendant zu Werthers Leiden, Werke und Briefe in drei Bänden, ed. Sigrid Damm, vol. 2, (Munich: Hanser, 1987), 380-412. All citations are from this edition. All translations from the German throughout this article are my own.

3 See Johann Wolfgang [von] Goethe, Aus meinem Leben: Dichtung und Wahrheit, Goethes Werke: Hamburger Ausgabe in 14 Bänden, ed. Lieselotte Blumenthal, Waltraud Loos, and Erich Trunz., 4th ed., vol. 10 (Hamburg: Wegner, 1966), 7-12. Scholars 
the innovative way in which Lenz's text uses "letters" - to be understood both as written messages and as literature - to stake out a critical stance on sentimental literature and its role in the construction of identity, since Der Waldbruder depicts the transformation of the reader or consumer of sentimental literary and epistolary texts, represented in the novel by the character Herz (in English, "Heart"), into the sentimental protagonist of a real-life novel. Lenz's critical stance on sentimental literature, both on the plot level and on the level of narrative perspective in Der Waldbruder, presents us not only with a radical reevaluation of the sentimental epistolary novel as represented by Goethe's Werther, but also with a revision of Lenz's own stance on the aesthetics of sentimental literature, to which he gave voice in his treatise "Letters on the Morality of the Sufferings of Young Werther" ("Briefe über die Moralität der Leiden des jungen Werthers"), also known as the "Werther Letters" (written 1774-75, published 1918).

Der Waldbruder has generated a fair amount of interest among Lenz scholars. Furst points out the grotesque distortion of the epistolary form in Der Waldbruder. ${ }^{4}$ Heine draws attention to the structure of Lenz's novel and to the great levels of deception by most of the characters; he interprets the text as a criticism of contemporary society. ${ }^{5}$ Stockhammer sees Der Waldbruder as a criticism of "politics" or tactical rationality in matters of the heart. ${ }^{6}$ Graf explores the construction of a literary closet in Der Waldbruder. ${ }^{7}$ Meinzer examines the psychoanalytic connections

trace the marginalization of Lenz both to Goethe's depiction of him and his work in Poetry and Truth as well as to Georg Büchner's pathological depiction of the writer in his novella Lenz (1839); see Andreas Huyssen, "1778, February: The Confusions of Genre," A New History of German Literature, ed. David E. Wellbery, Judith Ryan, Hans Ulrich Gumbrecht, Anton Kaes, Joseph Leo Koerner, and Dorothea E. von Mücke (Cambridge, MA: Belknap-Harvard UP, 2004) 399-404; esp. 399.

4 Lilian R. Furst, "The Dual Face of the Grotesque in Sterne's Tristram Shandy and Lenz's Der Waldbruder," Comparative Literature Studies 13 (1976): 15-21.

5 Thomas Heine, "Lenz's Waldbruder: Inauthentic Narration as Social Criticism," German Life and Letters 33 (1979-80): 183-89.

6 Robert Stockhammer, "Zur Politik des Herz(ens): J. M. R. Lenz' 'misreadings' von Goethes Werther," Jakob Michael Reinhold Lenz: Studien zum Gesamtwerk, ed. David Hill (Opladen: Westdeutscher Verlag, 1994) 129-39, esp. 137.

7 Roman Graf, "The Homosexual, the Prostitute, and the Castrato: Closet Performances by J. M. R. Lenz," Outing Goethe \& His Age, ed. Alice A. Kuzniar (Stanford: Stanford UP, 1996), 77-93. 
between the text and the life of the author. ${ }^{8}$ Kaminski reads Der Waldbruder against Georg Büchner's novella Lenz (1839) and Lenz's biography. ${ }^{9}$ Wurst points out the internal contradictions in the text regarding setting, chronology, plot, and narrative. ${ }^{10}$ Stephan examines the concepts of love and friendship in the novel, concluding that the text splits the paradigm "friend" into its positive (Herz) and negative (Rothe) elements as well as the paradigm "lover" into its positive (Countess Stella) and negative (Widow Hohl) components. ${ }^{11}$ For Lenz-Michaud, Der Waldbruder is both a satirical critique of Goethe's pathologization of Werther and a poetological call for protagonists that are freer and more tragic than Werther, whom, in her reading, Lenz viewed as determined by pathology. ${ }^{12}$ Martin reads the story of Herz as a pathography based on contemporary theories of nervous diseases. ${ }^{13}$ For Disselkamp, Lenz's text thematizes the utopian desires of the Enlightenment for transparency of character and for social cohesiveness, only to deny their fulfillment in the fictional universe of Der Waldbruder. ${ }^{14}$ Wurst, in a second article, reads Der Waldbruder against the background of Werther and the "Werther Letters," finding continuity in Lenz's criticism and fictional output; she ascertains a "poetics of conditional relations" ("Poetik der Bedingungsverhältnisse") that demands critical reflection from the

8 Elke Meinzer, "Die Irrgärten des J. M. R. Lenz: Zur psychoanalytischen Interpretation der Werke Tantalus, Der Waldbruder und Myrsa Polagi," Deutsche Vierteljahrsschrift für Literaturwissenschaft und Geistesgeschichte 68 (1994): 695-716.

9 Nicola Kaminski, "Herzbruder? 'Lenzens Verrückung' über die Jahrhundertschwelle," Das achtzehnte Jahrhundert 28 (2004): 46-64.

10 Karin Wurst, "Überlegungen zur ästhetischen Struktur von J. M. R. Lenz' Der Waldbruder ein Pendant zu Werthers Leiden," Neophilologus 74 (1990): 70-86.

11 Inge Stephan, "Das Scheitern einer heroischen Konzeption: Der Freundschaftsund Liebesdiskurs im Waldbruder," "Unaufhörlich Lenz gelesen ...": Studien zu Leben und Werk von J. M. R. Lenz, ed. Inge Stephan and Hans-Gerd Winter (Stuttgart: Metzler, 1994) 273-93.

12 Susanne Lenz-Michaud, “'Venus Urania allein kann dich retten mein Lieblingsdichter': Zur ästhetischen und anthropologischen Kritik an Goethes Werther im Werk von J. M. R. Lenz," Recherches germaniques 35 (2005): 1-21.

13 Ariane Martin, Die kranke Jugend: J. M. R. Lenz und Goethes "Werther" in der Rezeption des Sturm und Drang bis zum Naturalismus (Würzburg: Königshausen \& Neumann, 2002) 44-45.

14 Martin Disselkamp, "Ein 'Narr auf Charaktere': Literarische Charakterkonstitution zwischen moralischer Norm und anthropologischer Empirie in Lenz' 'Waldbruder,'" Lessing Yearbook 36 (2004-05): 161-83. 
reader. ${ }^{15}$ In this article, Wurst reads the "Werther Letters" against the grain, maintaining that Lenz's aesthetics demand both identification and critical reflection from the reader; for her, Lenz's poetological treatise explores various positions without favoring one authorized position in particular, and she sees Der Waldbruder as neither an affirming continuation of Werther nor as a criticism or refutation of rationalist, enlightened criticism of Werther, but rather as a "problematization" ("Problematisierung") of this complex of poetological issues. ${ }^{16}$

The following essay, however, reads Lenz's valorization of identificatory reading in the "Werther Letters" as a seriously espoused poetological position, and using this as its point of departure, this essay emphasizes the disjunction between Lenz's Werther criticism and his own experiment in the epistolary novel. In the "Werther Letters," Lenz does, to be sure, valorize identificatory reading in the face of Enlightened criticism, and he is, in fact, dissatisfied with what Goethe had accomplished with the epistolary form, as Lenz's own novel Der Waldbruder demonstrates. The following investigation focuses on the ways in which Lenz's Der Waldbruder uses the genre of the epistolary novel (paradigmatically exemplified by Werther) to explore the construction of identity and to critique sentimental literature and identificatory reading, aspects of this text which have received comparatively little attention in the critical literature up until now. Lenz's epistolary novel is more than a problematization of his poetological reception of Werther; instead, it places the dangers of the identificatory reading of sentimental literature front and center in the figure of Herz, in the reception of Herz via the other characters, and in the structure of the text itself, which demands critical reflection from the reader rather than enthusiastic identification.

When one thinks of Werther, one notes that his readings, particularly of Homer and Ossian, shape his view of the world. Scholars have long noted the deleterious effects of Werther's identificatory reading style. ${ }^{17}$ Bruce Duncan, for example, emphasizes that "the vitality of

15 Karin Wurst, "J. M. R. Lenz' Poetik der Bedingungsverhältnisse: Werther, die 'Werther-Briefe' und Der Waldbruder ein Pendant zu Werthers Leiden," J. M. R. Lenz als Alternative? Positionsanalysen zum 200. Todestag, ed. Karin Wurst (Cologne: Böhlau, 1992) 198-219.

16 Wurst, “J. M. R. Lenz' Poetik der Bedingungsverhältnisse” 219; see also 209-11.

17 See, for example, Bruce Duncan, “'Emilia Galotti lag auf dem Pult aufgeschlagen': Werther as (Mis-) Reader," Goethe Yearbook 1 (1982): 42-50; Horst Flaschka, Goethes "Werther": Werkkontextuelle Deskription und Analyse (Munich: Fink, 1987) 198-99; 
Werther's fantasy comes only at the expense of his reciprocal contact with the objective world. ${ }^{\prime 18}$ Werther's inappropriately identificatory reading style leads him to view the world through the lens of literature; at first, he imagines himself living within an idyllic Homeric symbolic universe, a reading-induced fantasy which is subsequently replaced by a sublimely terrifying Ossianic one. Werther's identification with these texts trains his imagination and leads him to focus more and more frequently on tormenting fantasized images, as Werther's editor notes: "[T]he sad images had become anchored within him, and his temperament moved only from one painful thought to the next." ${ }^{19}$

It is also the written word - this time, however, in the form of letters - that constructs Herz's sentimental love for the countess Stella on the level of the plot in Lenz's Der Waldbruder. Herz falls in love with Stella as he reads her messages, and his love mirrors his reading of sentimental novels. In contrast to Werther, however, Der Waldbruder depicts a society that is intimately involved in the construction of Herz's sentimental perspective, for various characters, including the countess herself and Herz's ostensible friend Rothe, are invested in manipulating Herz's feelings for Stella. Herz's need for idealized love is cultivated by the members of this society so that they may provide themselves with an idealized alternative perspective, creating in Herz a real-time version of a hero in a sentimental novel.

The varying narrative perspectives in the text also draw attention to the ways in which letters construct identity in the fictional universe of Der Waldbruder. Shlomith Rimmon-Kenan cites three main sources of unreliability when it comes to narrators: limited knowledge, personal involvement, and questionable values. ${ }^{20}$ The narrators in Der Waldbruder display all of these characteristics; they are all personally

Nicholas Boyle, Goethe: The Poet and the Age, vol. 1 (Oxford: Oxford UP, 1992) 176; Alice A. Kuzniar, "The Misrepresentation of Self: Werther versus Goethe," Mosaic: A Journal for the Interdisciplinary Study of Literature, 22.2 (1989): 15-28, esp. 17, 19; and Arnd Bohm, "'Klopstock!' Once More: Intertextuality in Werther," Seminar: A Journal of Germanic Studies 38 (2002): 116-33.

18 Duncan, "'Emilia Galotti lag auf dem Pult aufgeschlagen,"' 44.

19 "[D]ie traurigen Bilder hatten sich bei ihm festgesetzt, und sein Gemüt kannte keine Bewegung als von einem schmerzlichen Gedanken zum andern"; Johann Wolfgang [von] Goethe, Gedenkausgabe der Werke, Briefe und Gespräche, ed. Ernst Beutler, 24 vols. (Zürich: Artemis, 1948-64) 4: 477.

20 See Shlomith Rimmon-Kenan, Narrative Fiction: Contemporary Poetics (London: Routledge, 1994) 100-01. 
involved in the plot, they all have only limited knowledge of the events of the story, and they all have questionable values, as shall be demonstrated. Nonetheless, Der Waldbruder can more accurately be described as an "ambiguous narrative," to speak with Rimmon-Kenan's terminology, since it is difficult or impossible for the reader to assess the reliability of each of the narrators. ${ }^{21}$ Lenz scholars have, furthermore, pointed out that the "unreliability of communication" in Der Waldbruder forces the reader to reevaluate the plot repeatedly in order not only to determine the significance of the narrated events but also to ascertain what has in fact taken place. ${ }^{22}$ The ambivalent narrators include Herz, captive to his own sentimental subjectivity; Herz's manipulators, who set his feelings in motion and then mock him brutally; the ambiguously named Honesta, who styles herself both as objective and as a novelist, or creator of fiction; and Herz's supposed friend Rothe, who recasts Herz's biography in order to place himself in a better light, in much the same way as Goethe rewrote the story of Lenz's life, depicting him as "a passing meteor" that left no noticeable trace on German literature. ${ }^{23}$

Lenz's novel Der Waldbruder places itself squarely in the tradition of Goethe's Werther by engaging in the issues of sentimental love, reading, writing, and the dangers involved therein, yet in many ways, Lenz's epistolary novel asserts its independence from Goethe via its more critical depiction of the central role played by reading, writing, and selfrepresentation in the construction of identity. In this text, sentimental novels reproduce themselves in their readers, and eighteenth-century German society constructs a sentimental hero playing out his role in "real" life. On the one hand, Lenz thematizes the production and consumption of sentimental literary texts in Der Waldbruder as well as the ways in which each character's relationship to the written word creates his or her identity. On the other hand, Lenz's ironic restructuring of the epistolary form of the novel represents a shift in his perspective on sentimental literature as depicted in his earlier "Werther Letters," since Der Waldbruder provides readers and writers with a model of the epistolary novel that demands critical reflection rather than enthusiastic identificatory reading.

Lenz responded enthusiastically to Goethe's Werther. In literary-historical terms, this particular novel was an innovative step in the devel-

22 Heine, "Lenz's Waldbruder" 186. See also Wurst, “Überlegungen" 70-71, 77-78.

23 "[E]in vorübergehendes Meteor" (Goethe, Dichtung und Wahrheit 12). 
opment of the novel. The story is told in a series of letters written by Werther, making up the bulk of the novel; these letters are relativized only slightly by a fictional editor's interpolations, especially towards the end of the novel. This forces the readers to identify themselves with the protagonist, as readers are basically offered very little other than Werther's perspective. Among other things, it was the necessary identification of the reader with the protagonist as well as the radically enhanced representation of the sentimentalist cult of feeling that contributed to Werther's immense popularity among contemporary readers. Indeed, The Sufferings of Young Werther has even been called "the original cult book in Western fiction" and "perhaps the first cult novel of the modern world. ${ }^{\prime 24}$

The contemporary reception of the novel ranged from enthusiasm to condemnation, and the pleasures and dangers of identificatory reading played a prominent role in the discussion, as the following paradigmatic examples illustrate. The dangers of the readers' identificatory experience of the novel called forth the condemnation of the Hamburg pastor Johann Melchior Goeze: "[O]ne should think about how many of our youths could come into similar circumstances with Werther, for it is viewed as the greatest wisdom to fill up young souls with nothing but fantastic images and to drive their emotions far beyond their limits. ${ }^{\prime 25}$ The countess Auguste Stolberg practically memorized the novel, and her enthusiasm for the text excited in her a desire for knowledge of the author: "I have read almost nothing with such delight. I know almost the whole book by heart. ${ }^{\prime 26}$ However, even an enthusiast such as Stolberg felt the need for a clearer moral stance in the novel. She would have liked to have seen Werther's "errors" more clearly refuted or at

24 Thomas Reed Whissen, Classic Cult Fiction: A Companion to Popular Cult Literature (New York: Greenwood, 1992), 218; David Hill, introduction, Literature of the Sturm und Drang, The Camden House History of German Literature, vol. 6 (Rochester, NY: Camden House, 2003), 1-44; here: 37.

25 "Man bedenke [...], wie viele unsrer Jünglinge mit Werthern in gleiche Umstände geraten können [...], da es als höchste Weisheit angesehen wird, junge Seelen [...] mit lauter phantastischen Bildern anzufüllen und die Empfindungen in ihnen weit über ihre Grenzen hinaus zu treiben"; qtd. in Johann Wolfgang [von] Goethe, Goethes Werke: Hamburger Ausgabe in 14 Bänden, ed. Benno von Wiese and Erich Trunz., 6th ed., vol. 6 (Hamburg: Wegner, 1965), 526 [=HA].

26 "[I]ch [habe] fast nichts [...] mit dem Entzücken gelesen [...]. Ich weiß fast das ganze Buch auswendig" (qtd. in HA 6: 523-24). 
least pointed out to the readers as misconceptions; she feared otherwise that "many will believe that Goethe himself thinks like that." ${ }^{27}$

Stephan Schindler has pointed out that eighteenth-century critics were especially concerned about the dangers of the identificatory reading of sentimental novels, particularly when the readers were women or immature young men, for, it was thought, such readers lacked enough reason and virtue to maintain a critical distance from the reading material; rather than reading for edification or enlightenment, these problematic readers read for pleasure or for the gratification of their desires. ${ }^{28}$ David Wellbery has described Werther as an infantilized man, or as an immature young man in an infantile, oral state, ${ }^{29}$ and Werther's reading style is indeed the excessively identificatory reading style reviled by the eighteenth-century critics described in Schindler's essay. Moreover, the reception of Werther gave rise to the same overly identificatory reading for sensual pleasure. Indeed, Goethe attempted to work against the enthusiastically identificatory reception of his novel by incorporating new portions of text into the second edition of 1787 in the hope of creating more distance between the readers and the characters. ${ }^{30}$ Goethe's transition to a more critical stance regarding sentimental literature can be seen in his play The Triumph of Sentimentalism (Der Triumph der Empfindsamkeit, written 1777, premiered 1778, published 1787). In this play, Prince Oronaro, a Werther-like character who suffers from an excess of sentiment and from his love for a married woman, is made ridiculous by his fetishization of a life-sized doll of his beloved, the heart of which is made up of a sack of sentimental novels, including Werther. When several ladies-in-waiting discover the novels which make up the sentimental core of Oronaro's ersatz lover, they express the desire to read them, yet King Andrason forbids them to read the texts due to their morally detrimental influence.

28 See Stephan K. Schindler, "The Critic as Pornographer: Male Fantasies of Female Reading in Eighteenth-Century Germany," Eighteenth-Century Life ns 20.3 (1996): 66-80.

29 See David E. Wellbery, "Morphisms of the Phantasmatic Body: Goethe's The Sorrows of Young Werther," Body \& Text in the Eighteenth Century, ed. Veronica Kelly and Dorothea von Mücke (Stanford: Stanford UP, 1994) 181-208.

30 See David Hill, introduction, Literature of the Sturm und Drang, ed. David Hill, The Camden House History of German Literature, vol. 6 (Rochester, NY: Camden House, 2003) 1-44, esp. 37. 
In his "Werther Letters," Lenz espoused a position that ran counter to the Enlightenment critics of Werther; he extolled the nonrational identificatory pleasure derived from reading the novel and found it inappropriate to seek a moral message in the text: "That one can, however, sit down and inquire in cold blood about the morality of The Sufferings of Young Werther [ - that I can not endure], since my own senses disappeared while I was reading it. Completely and magically transported into his world, I loved with Werther, suffered with Werther, died with Werther. ${ }^{\prime 31}$ In this treatise, Lenz is propagating a new aesthetics of the novel. The purpose of literature is no longer to transmit moral messages to its audience but rather to captivate the readers with its beauty and completeness: "Why are they always reading moral goals into the [work of] a poet, when he had never even thought of them[?] [...] [Goethe] wanted nothing more and nothing less than to depict the sufferings of young Werther and to follow them to their ultimate goal [...]." ${ }^{\prime 32}$ Literature becomes for Lenz a means of educating the audience emotionally; this is where the morality of literature lies: "Let us therefore investigate the morality of this novel for once; not the ultimate moral purpose that the poet has dished up for us (for that is where he stops being a poet), but rather the moral effect that the reading of this novel could have and would have to have on the hearts of the audience. ${ }^{\prime 33}$ For Lenz, it is the identificatory reading style that the Werther novel encourages which can morally educate the reading public. The novel activates the emotions in the hearts of the readers, thereby making them more aware of their inner moral sentiments to a much greater extent than coldly reasoning over the moral lessons of literature could ever do: "Every novel that knows how to touch and move the heart in its most hidden

31 "Daß man aber mit eben dem kalten Blute sich hinsetzt und nach der Moral der Leiden des jungen Werthers fragt, da mir als ich's las die Sinnen vergingen, ich ganz in seine Welt hineingezaubert mit Werthern liebte, mit Werthern litt, mit Werthern starb - das kann ich nicht vertragen"; Jakob Michael Reinhold Lenz, "Briefe über die Moralität der Leiden des jungen Werthers," Werke und Briefe in drei Bänden, ed. Sigrid Damm, vol. 2 (Munich: Hanser, 1987) 673-90; here: 675-76.

32 "Warum legt man dem Dichter doch immer moralische Endzwecke unter, an die er nie gedacht hat. [...] Nichts mehr und nichts weniger als die Leiden des jungen Werthers wollt er [Goethe] darstellen, sie bis an ihr Endziel verfolgen [...]" (Lenz, "Briefe" 675).

33 "Laßt uns also einmal die Moralität dieses Romans untersuchen, nicht den moralischen Endzweck den sich der Dichter vorgesetzt (denn da hört er auf Dichter zu sein) sondern die moralische Wirkung die das Lesen dieses Romans auf die Herzen des Publikums haben könne und haben müsse" (Lenz, "Briefe" 676-77). 
recesses must also improve the heart, no matter what [the novel] looks like. [...] Werther's value lies in the fact that he makes us aware of passions and emotions that one vaguely perceives in oneself but that one is unable to name. That is the value of every poet." ${ }^{34}$

This identificatory reading style is, however, exactly what Werther's critics denounced as dangerous. Lenz defuses their arguments by claiming that it is impossible to imitate Werther, since he is only an image, an image which conveys only the moral lesson that the reader finds most appropriate: "Werther is an image, gentlemen, an [...] example [...], and it is left up to your own genius to make the best use of it. [...] Werther is an image, and it is a physical and metaphysical impossibility to imitate that image completely. ${ }^{\prime \prime 3}$ This line of argumentation is perhaps not very convincing and may have played a role in Friedrich Heinrich Jacobi's decision not to publish Lenz's "Werther Letters" in 1775, as he felt that they would only resonate with those who were already in agreement with Lenz about Werther. ${ }^{36}$

Given Lenz's enthusiasm for the identificatory consumption of sentimental novels, it seems strange that in his own epistolary novel Der Waldbruder, the subtitle of which invites the recipients of the text to read it against the background of Werther, one finds a completely different dynamic, for this novel is a strong critique of the dangers involved in reading sentimental literary and epistolary texts. Der Waldbruder juxtaposes Herz, all of whose problems stem from his identificatory reading style, with other characters who are represented as writers rather than as readers and who are consciously aware of the act of writing as a means of self-representation.

The protagonist Herz falls in love with the countess Stella when he reads her letters; Herz says her most inmost being "shines forth from her letters, which I have read, which I have with me and carry [with me] over my naked heart," and she becomes, as a result, the "object

34 "[J]eder Roman der das Herz in seinen verborgensten Schlupfwinkeln anzufassen und zu rühren weiß, [muß] auch das Herz bessern [...] er mag aussehen wie er [der Roman] wolle. [...] Eben darin besteht Werthers Verdienst daß er uns mit Leidenschaften und Empfindungen bekannt macht, die jeder in sich dunkel fühlt, die er aber nicht mit Namen zu nennen weiß. Darin besteht das Verdienst jedes Dichters" (Lenz, "Briefe" 682; original emphasis).

35 "Werther ist ein Bild, meine Herren, ein [...] Exempel [...] [,] und [es ist] eurem eigenen Genie überlassen [...], die nützlichste Anwendung davon zu machen. [...] Werther [ist] ein Bild [...], welchem nachzuahmen eine physische und metaphysische Unmöglichkeit ist" (Lenz, "Briefe" 685). 
of my lonely worship. ${ }^{\prime 37}$ Herz's love for Stella is entirely mediated by the written word, for Herz has never seen Stella, and at a masquerade, he even mistakes another woman for the countess. In fact, the letters that reveal Stella's soul and cause Herz to fall in love with her were not written to him at all but to the Widow Hohl, from whom he rents a room. Herz's sentimental love for the countess is thus channeled through the epistolary texts which she has written to the Widow Hohl (in English, "Hollow") but also through his own reading of sentimental novels. Honesta describes her belief that Herz is modeling himself on Werther; she calls him "a new Werther" and says that everyone "regrets the damage that such writings bring on." ${ }^{38}$ The effects of his reading prove disastrous, as various characters report; Honesta says that his literary love for the countess has caused his reason, his genius, and his talents to go into rapid decline, and she claims that he "is now swimming in nothing other than blessed dreams of love and honor [...] waking up will be horrible. ${ }^{\prime 39}$ Rothe points out that Herz's readings have affected his perceptions of the world around him: "All characters and opinions that differ from his own seem to him so great, [...] that he believes that he is surrounded by nothing but extraordinary people, gigantic heroes of virtue or villains, and one cannot make him comprehend that the greatest number of people are mediocre. ${ }^{\prime 40}$ Rothe attributes Herz's problems in love to an excess of sentimentality that he has derived from his readings; Rothe describes the history of Herz's love, and it follows the same pattern three times over: Herz projects an ideal image gained from his reading of, among other things, "Goethe's [...] novels," onto an unexceptional woman who then goes on either to betray him or to lose interest in him. ${ }^{41}$ Rothe finds that "the ideas

37 " [...] leuchtet aus ihren Briefen, die ich gelesen habe, die ich bei mir habe und auf meinem bloßen Herzen trage" (385). He says that she becomes the "Gegenstand[] meiner einsamen Anbetung" (Lenz, Waldbruder 385).

38 "[E]inen neuen Werther [...][;] [j]edermann redt davon und bedaurt das Unheil, das solche Schriften anrichten" (Lenz, Waldbruder 389).

39 "Er schwimmt jetzt in lauter seligen Träumen von Liebe und Ehre, [...] das Aufwachen wird schrecklich sein" (Lenz, Waldbruder 406). See also 404.

40 "Alle Charaktere und Meinungen die von den seinigen abgehen, scheinen ihm so groß, [...] daß er mit lauter außerordentlichen Menschen, gigantischen Tugendhelden oder Bösewichtern umgeben zu sein glaubt, und ihm gar nicht begreiflich gemacht werden kann, daß der größte Teil der Menschen mittelmäßig ist" (Lenz, Waldbruder 409).

41 "Goethens Romanen" (Lenz, Waldbruder 410). 
from the years of his youth [...] have never left him, [even] in all of his misfortunes. ${ }^{\prime 42}$ Wurst has pointed out that Herz is not in love with a particular woman but is, instead, in love with love, and Stephan has discussed the discrepancy between Herz's idealized notions of his beloved and the real women onto whom he has, in the past, projected his desires. ${ }^{43}$ Crucial within the context of my reading of the text is, however, the fact that it is Herz's unreflective consumption of sentimental literature that has made him vulnerable to falling in love not with the countess Stella but with a construct of the beloved, whose place the countess Stella fills.

Herz constructs himself as a sentimental lover by channeling his desire for the countess through the medium of literary and epistolary texts. Once he is in the same room with her, when she visits the Widow Hohl, he is capable only of stammering and staring at the ground. He speaks to the Widow Hohl, as does the countess, but Herz and Stella do not speak to each other. Nonetheless, Herz claims that their love for each other is communicated via glances and facial expressions. Words cannot express his feelings for the countess: "I received only sidelong glances from her, and she saw my eyes always glued to the floor, and yet our glances met each other and spoke into the innermost part of our heart, what no human language will be able to express. ${ }^{\prime 44}$ Herz is thus depicted as a reader or consumer of literary texts who is incapable of expressing his feelings and experiences by means of language. Nonetheless, he writes a great number of letters to his friend Rothe in an attempt to describe his emotions. In this way, Herz serves as a counterpart to Werther, who fills his letters to his best friend Wilhelm with sentimental perceptions about love, nature, and art, among other things, but Herz is depicted as ineffectual because of this. He is a failed writer who, in his youth, forfeited a stipend from a benevolent guardian due to his inability to correspond often enough to maintain their relationship, and even now, when he does correspond with Rothe, his letters are incapable of expressing what he wants them to express.

42 Rothe says that "die Ideen seiner Jugendjahre [...] bei allen seinen Unglücksfällen ihn nie verlassen haben" (Lenz, Waldbruder 411).

43 See Wurst, “Überlegungen" 78, 83, and Stephan, “Das Scheitern" 289.

44 "Ich bekam nur Seitenblicke von ihr, und sie sah meine Augen immer auf den Boden geheftet und doch begegneten unsere Blicke einander und sprachen ins Innerste unsers Herzens was keine menschliche Sprache wird ausdrücken können" (Lenz, Waldbruder 392). 
The role played by society in the propagation of this sentimental conception of love calls the consumption of sentimental literature into question. In contrast to the society in The Sufferings of Young Werther, the community in Der Waldbruder is actively and intimately involved in the construction of Herz's identity as a sentimental lover. The Widow Hohl, the countess Stella, Rothe, and Plettenberg are all involved in creating and fostering Herz's love for Stella. These members of the community care for and tend his emotions in order to cultivate him as their "Other," the hero of a sentimental novel. For Rothe, Herz's sentimental enthusiasm for the countess provides comic relief. Rothe styles himself as a gallant lover, who is incapable of any kind of emotional attachment to a woman, and he speaks of his sexual exploits as fictional narratives: "I count for something among women, and only because I am frivolous with them. As soon as I get into the higher emotions, we're finished; [...] our little love stories come to an end." ${ }^{\prime 45}$ The style of Rothe's "love stories" is, however, radically different from the sentimental love expressed in Herz's letters, which gives Rothe and the community of which he is a part "material to laugh about," since it is "so terribly different from our way of loving." ${ }^{\prime 46}$ In fact, Herz's idealized love for Stella has become so well-known that groups of visitors travel from the city to his shack in the forest in order to see him for themselves and ask him questions about Stella.

Once it has been introduced, Herz's sentimental reverence for his beloved is immediately and comically relativized when we read in the fourth letter of the novel that he has never even met Stella and that he has started stalking a certain Frau von Weylach, whom he erroneously takes to be Stella, thereby making himself a figure of fun for the community of which he has been a part. Fräulein Schatouilleuse writes to Rothe: "Ha ha ha, I am laughing my head off, my dear Rothe. Are you aware of the fact that Herz is in love with the wrong woman[?] I can't write, I'm bursting with laughter." ${ }^{47}$

45 "[I]ch gelte ein wenig bei den Frauenzimmern, und das bloß, weil ich leichtsinnig mit ihnen bin. Sobald ich in die hohen Empfindungen komme, ist's aus mit uns, [...] unsere Liebesgeschichtchen haben ein Ende" (Lenz, Waldbruder 384).

46 "Stoff zum Lachen [...] Es sticht alles so schrecklich mit unsrer Art zu lieben ab" (Lenz, Waldbruder 384).

47 "Ha ha ha, ich lache mich tot, lieber Rothe. Wissen Sie auch wohl, daß Herz in eine Unrechte verliebt ist. Ich kann nicht schreiben, ich zerspringe für Lachen" (Lenz, Waldbruder 383). 
The other characters foster Herz's love for Stella, but not for their own identificatory experiential pleasure; instead, they are involved in the construction of literature, and this is the satisfactory game that they play at Herz's expense. The other characters in the novel are portrayed as effective writers who are conscious of writing as an act of self-representation. Honesta, whose name at first glance suggests "honesty" and whose letters make up the third part of the novel, seems to clear up many questions about Herz and his experiences, yet several factors cast doubt upon her narration. She spreads false information in her report by maintaining that Herz has fallen in love with the Widow Hohl, which he has not, and that Stella is having a portrait of herself made for Herz, when it is indeed for Rothe. Honesta also casts her material in a positive light, when it is clear from other letters that this is probably not the case; perhaps her name refers instead to "honett" or "honorable," a term that figures prominently in Lenz's play The Soldiers (Die Soldaten, 1776). Finally, Honesta closes her last letter with the assertion that she would make a good novelist, thereby suggesting that her reports about Herz might contain some doses of fiction.

The Widow Hohl is also depicted as a creator of fiction. She creates the epistolary novel that leads to Herz falling in love with Stella when she selects letters from the countess's correspondence to show to him, strategically omitting any letters that refer to Stella's longstanding engagement to Plettenberg. Hohl's plan is to get Herz to fall in love with the inner qualities of the countess, and then, once Hohl reveals to Herz that Stella is engaged, Herz will transfer his love onto Hohl herself. Honesta associates Hohl with the theater, for she describes this plan variously as "a coup de théâtre," as containing a "catastrophe," as a "play" or a "drama" with "roles [...] masterfully performed," and as something that may very well end "tragically" rather than "comically." ${ }^{\text {" }}$ Stella is also portrayed as a literary artist, in that her letters are written in such a manner that one "reads them with the same interest with which one reads the most well-written novel. ${ }^{\prime 49}$ Rothe expects Plettenberg to have a critical relationship to the written word and expects his narration of Herz's romantic history to call forth in

48 Honesta uses the following words and phrases to describe Hohl's machinations: "Theaterstreich," "Katastrophe," "Stück," "Drama," "die Rollen wurden meisterhaft abgespielt," "das Stück könne eher tragisch als komisch endigen" (Lenz, Waldbruder 403).

49 "[M]an [liest] sogar ihre kleinsten Kommissionen mit eben dem Interesse [...] als den wohlgeschriebensten Roman" (Lenz, Waldbruder 402). 
Plettenberg wonderment but probably not sympathy, the catchword of identificatory reading. Rothe also uses writing in a conscious manner in order to further his own aims. In his letters to Plettenberg, Rothe pathologizes Herz, his rival for the affections of Stella, with whom he is possibly already having an affair, in much the same way that Goethe pathologized Lenz in Poetry and Truth, a depiction that had long-lasting consequences for Lenz's literary reputation. ${ }^{50}$ Since most of the characters in Der Waldbruder use their writing for conscious self-representation and for the effective manipulation of their audience, they do not develop an excess of sentimentality as Herz does. Because Herz attempts to use writing to reproduce the sensory impressions and idealized emotions that are the result of his identificatory reading of sentimental literature, he becomes a victim of sentimentality and a figure of fun for the community.

The multiple narrative perspectives, the information missing between the lines of the letters, and the conflicting and contradictory statements of the various narrators constantly remind the reader that, in this fictional epistolary universe, it is impossible to ascertain what the objective facts of the situation are. Whereas in Werther, the reader is faced for the most part with only the protagonist's subjective experience recounted through his letters, with the addition of some material by the editor, Der Waldbruder uses a multiplicity of narrative perspectives, all of them displaying, to some extent, the characteristics of unreliability discussed by Rimmon-Kenan: limited knowledge, personal involvement, and questionable values. ${ }^{51}$ Lenz's text provides the reader, on the one hand, with an indictment of the manipulative community of letter writers attempting to further their sexual goals at the expense of others' feelings - particularly in the case of Rothe and of Hohl - and on the other hand, with a nuanced indictment of sentimental literature using the example of Herz. The text invites readers to think critically about the role of writing, reading, and self-representation in the text in order to perceive the significance of this challenging novel, in which Lenz demonstrates what can be done with the epistolary genre in order to critique identificatory reading. Schindler points out that the sentimental novel typically "incorporated its own manual for proper

50 For a recent, detailed examination of Goethe's representation of Lenz, see Markus Joch, “Wer verliert, gewinnt: J. M. R. Lenz' Werkphase 1774-1776 und ihre paradoxe Ökonomie," Zeitschrift für Germanistik 17.3 (2007): 533-46, esp. 533-37.

51 See Rimmon-Kenan, Narrative Fiction 100-01. 
use" by depicting characters reading novels. ${ }^{52}$ Lenz's text provides the reader with directions for its own use as well. The reader encounters a variety of narrative perspectives in the brief epistolary novel, and these narrative perspectives provide the reader with conflicting information and irreconcilable attitudes on love and sexual behavior. The text relativizes, on the one hand, Herz's sentimentalism by means of the mocking commentaries of the other characters - Fräulein Schatouilleuse, for example, finds comic relief in Herz's love for Stella - and, on the other hand, the attitudes of the other (unsentimental) characters such as Rothe and the Widow Hohl are revealed to be calculating and manipulative attempts to satisfy their own sexual desires at the expense of others - Rothe manipulates Herz and Plettenberg in his attempts to consummate his desire for Stella; the Widow Hohl stokes Herz's love for Stella in the hopes of getting him to transfer his feelings onto Hohl herself eventually. The readers arrive at these conclusions only by reading between the lines, by reading the varying narratives against one another, or in other words, by accessing their reason in order to read critically rather than adopting an identificatory reading style.

In Der Waldbruder, Lenz distances himself in practice from the enthusiasm he demonstrated for the identificatory consumption of sentimental literary texts in his theoretical treatise "Letters on the Morality of the Sufferings of Young Werther." Lenz's innovative and challenging restructuring of the genre of the epistolary novel represents his critical stance towards the unreflective and identificatory consumption of sentimental literature, a stance which can also be seen in his dramas. In The Tutor (Der Hofmeister, 1774), Läuffer and Gustchen's ill-fated love affair is spurred on by their reading of texts such as Romeo and Juliet, the correspondence of Abélard and Héloise, and Rousseau's Julie, ou La nouvelle Héloise, and, what is more to the point, by their imagining themselves in the roles of the protagonists. In The Soldiers, a group of men discusses the moral dangers of the theater, for plays often depict methods of seduction, which can then be put into practice by the audience members once they leave the theater. These dangers are then depicted in The Soldiers when Marie Wesener attends a theater production with Desportes, who then has little problem seducing her and precipitating her downfall. Despite Lenz's enthusiasm for and defense of The Sufferings of Young Werther, he wrote an epistolary novel that - by means of its innovative use of narrative perspective and 
via its plot, which pits the gallant intrigues of the community against the ridiculous sentimentality of Herz's love for Stella - raises serious and lingering questions about the deleterious effects of the consumption of sentimental literature. Der Waldbruder becomes A Counterpart to Werther's Sufferings in that it offers readers a critical detachment from its sentimental protagonist and an implicit warning about the dangers of the unreflective consumption of literary and epistolary texts.

EDWARD T. POTTER

Mississippi State University 